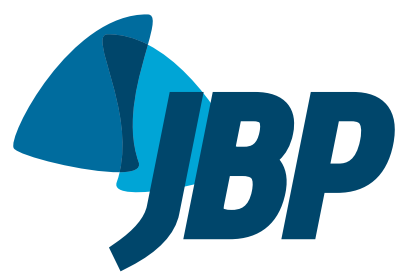

1. Programa de Pós-Graduação em Ciências Pneumológicas, Universidade Federal do Rio Grande do Sul, Porto Alegre (RS), Brasil.

2. Serviço de Pneumologia, Hospital de Clínicas de Porto Alegre Porto Alegre (RS), Brasil.

3. Serviço de Reumatologia, Hospital de Clínicas de Porto Alegre Porto Alegre (RS), Brasil.

4. Instituto de Doenças do Tórax, Faculdade de Medicina, Universidade Federal do Rio de Janeiro, Rio de Janeiro (RJ), Brasil.

a. (D) http://orcid.org/0000-0003-2288-635

b. (D) http://orcid.org/0000-0001-5868-7974

c. (D) http://orcid.org/0000-0002-9564-9376

d. (iD http://orcid.org/0000-0003-4424-0113

e. (D) http://orcid.org/0000-0003-0132-4325

f. (iD) http://orcid.org/0000-0003-0229-7912

g. (D) http://orcid.org/0000-0003-3250-6738

h. (D) http://orcid.org/0000-0003-0230-2734

Received: 24 January, 2019.

Approved: 27 February, 2019

Study carried out in the Programa de Pós-Graduação em Ciências

Pneumológicas, Faculdade de Medicina, Universidade Federal do Rio Grande do

Sul, Porto Alegre (RS), Brasil.

\title{
Latent tuberculosis infection in patients with rheumatic diseases
}

\author{
Camila Anton 1,2,a, Felipe Dominguez Machado 1,2,b, \\ Jorge Mario Ahumada Ramirez ${ }^{1,2, c}$, Rafaela Manzoni Bernardi ${ }^{1,2, d}$, \\ Penélope Esther Palominos ${ }^{3, \mathrm{e}}$, Claiton Viegas Brenol ${ }^{3, \mathrm{f}}$, \\ Fernanda Carvalho de Queiroz Mello ${ }^{4,9}$, Denise Rossato Silva ${ }^{1,2, \mathrm{~h}}$.
}

\begin{abstract}
Most people infected by Mycobacterium tuberculosis (Mtb) do not have any signs or disease symptoms, a condition known as latent tuberculosis infection (LTBI). The introduction of biological agents, mainly tumor necrosis factor (TNF) inhibitors, for the treatment of immune-mediated diseases such as Rheumatoid Arthritis (RA) and other rheumatic diseases, increased the risk of reactivation of $L T B I$, leading to development of active TB. Thus, this review will approach the aspects related to LTBI in patients with rheumatologic diseases, especially those using iTNF drugs. For this purpose it will be considered the definition and prevalence of LTBI, mechanisms associated with diseases and medications in use, criteria for screening, diagnosis and treatment. Considering that reactivation of $L T B I$ accounts for a large proportion of the incidence of active TB, adequate diagnosis and treatment are crucial, especially in high-risk groups such as patients with rheumatologic diseases.
\end{abstract}

Keywords: Tuberculosis; Latent tuberculosis; Tuberculin skin test; Anti-TNF therapy; Tumor necrosis factor-alpha; Rheumatoid arthritis.

\section{INTRODUCTION}

The most people infected by Mycobacterium tuberculosis (Mtb) has no signs or symptoms of the disease, a condition known as Tuberculosis Latent Infection (LTBI). According to the World Health Organization (WHO), about 2 to 3 billion people worldwide are infected by Mtb; including 5 to $15 \%$ will progress from LTBI to active symptomatic disease during their lifetime. The reactivation of LTBI is responsible for a large proportion of cases of tuberculosis (TB) active, which makes diagnosis and treatment crucial, especially in high-risk groups. ${ }^{(1-3)}$

The introduction of biological agents, especially tumor necrosis factor (iTNF) inhibitors, to treat immune-mediated diseases such as rheumatoid arthritis (RA) and other rheumatic diseases has increased the risk of developing TB. ${ }^{(4)}$ The iTNF can promote the reactivation of TB to neutralize TNF, which protects the host against Mtb and plays a key role in granuloma formation which limits the extent of injury. ${ }^{(1,5,6)}$
Thus, the objective of this article is to review the aspects related to LTBI in patients with rheumatologic diseases, especially in those using iTNF drugs. For this purpose, it will be discussed the definition and prevalence of LTBI, the mechanisms associated with diseases and medications, as well as criteria for screening, diagnosis and treatment of LTBI.

\section{DEFINITION AND MECHANISMS OF LTBI IN RHEUMATIC DISEASES}

According to WHO, the LTBI is characterized by the presence of persistent immune response to Mtb without clinical evidence of active disease. (7) The chance of infection after exposure to TB bacillus is about $30 \%$ in healthy people, depending on the degree of exposure, infectivity of the index case, and the individual's immune factors. Approximately $5 \%$ of people cannot prevent the multiplication of bacillus and then develop the active disease soon after infection. Other $5 \%$ later become ill

Correspondence to:

Denise Rossato Silva. Rua Ramiro Barcelos, 2350, Sala 2050, Bairro Santa Cecília, CEP: 900035-903, Porto Alegre, RS, Brasil.

Tel.: 51 3359-8000. E-mail: denise.rossato@terra.com.br

Financial support: None. 
by reactivation of latent infection or as a consequence of a new exposure to the bacillus. Besides that, several factors may increase the risk of reactivation of TB, such as disease or immunosuppressive treatments used in rheumatic diseases. ${ }^{(8)}$

According to research conducted in patients with RA, even those who have never used iTNF have a risk of TB of two to ten times greater compared to the general population. ${ }^{(9-13)}$ In one such study, which was a prospective population-based cohort, ${ }^{(9)}$ in Sweden, demonstrated that Rheumatoid Arthritis (RA) patients not exposed to biological had a four-fold increased risk of TB compared to the general population, noting that the risk TB is independent of the use of ITNF and that probably is associated with immunosuppression linked to the disease and the use of other medications such as corticosteroids.

In any case, the use of iTNF is related to a risk of TB of 2 to 30 times greater, depending on the medication used and the place of study. ${ }^{(9-14)}$ It is known that TNF plays a critical role in the host's response to infection, since it influences the transport of cells to the infectious focus, promoting the formation of granuloma capable of containing the disease progression, as well as increasing the phagocytic capacity of the macrophages and the death of viable intracellular bacteria. In addition, TNF is responsible for maintaining the structural integrity of the granuloma. Thus, the use of TNF antagonists leads to the resumption of mycobacterial growth within the granuloma, resulting in even its structural disintegration (Figure 1). ${ }^{(15,16)}$

Another class of medications used in the treatment of rheumatic diseases is not biological iTNF such as: Antiinterleukin-1 (IL-1), Anakinra (ANK), receptor inhibitor of the IL-6 tocilizumab (TCZ), Anti-CD20 Rituximab (RTX), stimulus blocker of abatacept T-lymphocytes (ATB), Anti-IL-12 and IL-23 Ustekinumab (UST), and Anti-IL-17 Secukinumab (SEC). According to data from controlled clinical trials and national registries, biological non-iTNF not has a negligible risk of TB reactivation. Thus, probably, in these cases, the tracking LTBI is not necessary and these medicaments are the safest option in patients with increased risk of reactivation of TB. ${ }^{(17)}$

\section{DIAGNOSIS OF LTBI}

For the diagnosis of LTBI, there is the Tuberculin Skin Test (TST), also known as the Mantoux test or Mendel-Mantoux test, and tests IGRA (InterferonGamma Release Assay in English). Both do not differentiate infection from active disease, so they are only used to diagnose LTBI. ${ }^{(7)}$

\section{Tuberculin Test (TST)}

The TST has been used for many years for the diagnosis of LTBI. Two to ten weeks after Mtb infection, T-lymphocytes become responsive to components of the bacillus, and tuberculin antigen injection triggers off a delayed hypersensitivity reaction. The tuberculin used in Brazil (PPD RT23-) is applied using the same technique and equipment recommended by WHO, intradermal in the anterior part of the left forearm, at a dose of $0.1 \mathrm{ml}$, equivalent to $2 \mathrm{TU}$ (tuberculin units). The TST reading is performed 48 to 72 hours after application (with the possibility of extending for up to 96 hours), measuring the transverse diameter of the hardened area in millimeters and discarding the surrounding erythema. In patients who are candidates for the use of biologicals for rheumatologic diseases, the criterion $\geq 5 \mathrm{~mm}$ is used to indicate treatment of LTBI. ${ }^{(8,18)}$

False-positive results (TST positive and LTBI negative) may occur in individuals infected by non-tuberculous mycobacteria or vaccinated people with the CalmetteGuérin bacillus (BCG), especially if vaccination occurs after the first year of life, when BCG produces greater and more lasting reactions. However, the effect of neonatal BCG on TST decreases gradually in the first seven years of life. ${ }^{(19)}$ Besides that, immunization with BCG does not have significant influence on the TST response after ten years. ${ }^{(20)}$ In endemic countries, the positivity of the TST reflects most likely a high prevalence of LTBI than a result of vaccination with BCG. ${ }^{(19,20)}$

On the other hand, false-negative results (negative TST and positive ILTB) may occur in immunosuppressed patients receiving corticosteroids (doses of prednisone> $15 \mathrm{mg}$ / day) and other immunosuppressants, a situation fairly common in individuals with rheumatologic diseases. Furthermore, in RA, T cell function is altered, which could result in inability to develop an appropriate response to TST. ${ }^{(21)}$ The exact mechanism for this change is not fully elucidated, but it is known that in RA there is a decrease in the amount and function of regulatory $T$ cells (CD4 + and CD25 +), and the number of $\mathrm{CD} 4+\mathrm{T}$ cells determines the magnitude of response to TST. ${ }^{(22,23)}$

In fact, lower rates of positivity for TST have been described in patients with RA. ${ }^{(21,24-28)}$ In a case control study ${ }^{(27)}$ conducted in Turkey, the frequency of TST positivity in patients with RA (29.8\%) was lower than in patients with ankylosing spondylitis (AE) (65.9\%). In another study, ${ }^{(28)}$ held in Brazil, the prevalence of TST positive in the control group was higher (33.3\%) compared to RA patients $(14.6 \%)(p=0.034)$.

Besides these, another TST disadvantage is the possibility of booster effect. Individuals infected by Mtb may have the ability to react to TST reduced over time because of the loss of T-lymphocyte response from memory, which could cause a false negative result in a first TST. The booster effect occurs when the second TST, performed from one to three weeks after the first, has resulted $\geq 10 \mathrm{~mm}$, with an increase of at least $6 \mathrm{~mm}$ in relation to the previous TST. Thus, whenever TST is repeated within three weeks, the results should be interpreted with caution so as not to confuse the booster effect with tuberculin turn and to have a false indication of LTBI. However, the booster effect indication research (TST repeat up in to three weeks) is currently restricted to health professionals, 


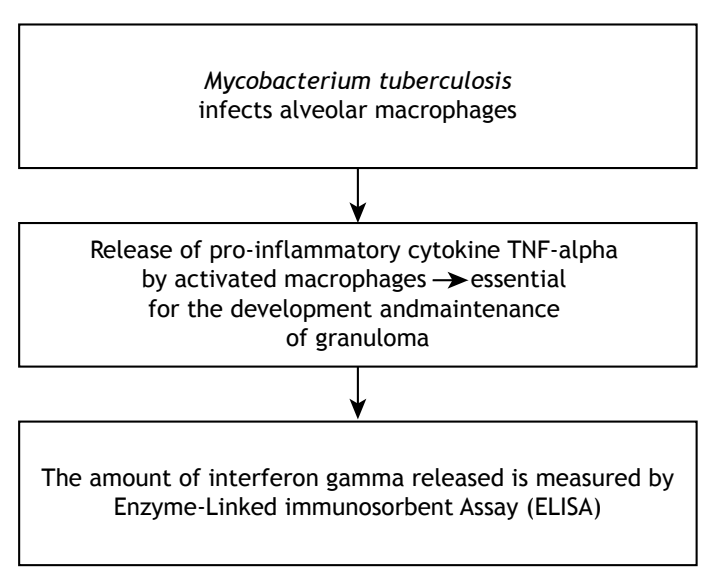

Figure 1. Effects of anti-TNF in granuloma formation.

which were negative in the first TST for subsequent annual follow-up of tuberculin conversion. ${ }^{(8)}$

Despite its limitations, such as low sensitivity in immunosuppressed patients, cross reactions with BCG vaccination and infections by non-tuberculous mycobacterial, TST is still the most widely available test for clinical practice. ${ }^{(8)}$

\section{IGRA test}

The IGRA tests detect the production of interferon- $\gamma$ (IFN- $\gamma$ ) derived from $T$ in the peripheral blood activated by specific antigens. Nowadays, there are two commercial kits available: the QuantiFERON-TB Gold in tube (QFT), based on the ELISA method, and has been validated for use in Brazil, and the T-SPOT.TB, based on simplified enzyme immunoassay (ELISPOT). The QFT test uses the antigens of the RD1 region of Mtb, ESAT-6, CFP-10 and TB7.7 to measure the IFN-Y responses of patients (Figure 2 ) and is considered positive if the IFN value $-\gamma$ (quantified in IU $/ \mathrm{mL}$ ) is above the upper limit of the test. And concerning the T-SPOT.TB test estimates the number of IFN- $\gamma$ producing cells and is considered positive if the number of cells is greater than the negative control.

They have an excellent specificity (90-100\%) for not being affected by BCG vaccination and, like TST, a good level of agreement, although discordant results may occur in up to $15 \%$ of the patients, depending on the population studied (HIV-positive people, cirrhotic, individuals with autoimmune diseases, transplanted and vaccinated by BCG). ${ }^{(29-31)}$ False-positive and falsenegative results may occur in IGRA tests because of mitogenic contamination of isolated cells. ${ }^{(32)}$ However, a meta-analysis presented in 2016, ${ }^{(33)}$ which included 11 studies, demonstrated that, in patients with previous BCG vaccination or corticosteroid use, IGRA tests would be the best choice to identify patients with LTBI because they have fewer false positive results and false negatives compared to TST.

The realization of the examination on a single patient visit and the speed of the results are other advantages of the IGRA tests. However, the high

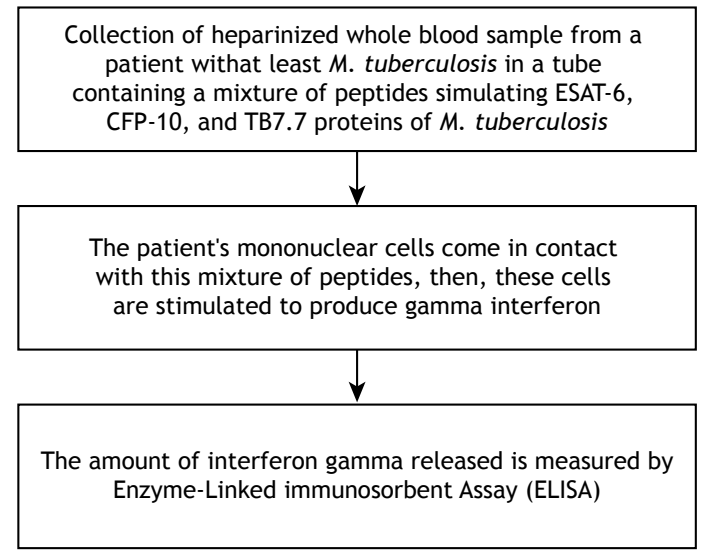

Figure 2. QuantiFERON-TB Gold in tube (QFT).

$\operatorname{cost}_{,}{ }^{(8)}$ the need for personnel, specialized equipment, the possibility of conversion and reversal in serial tests are disadvantageous. The clinical significance of conversions and reversals in IGRA tests remains unclear, but it is known that they may be caused by the use of corticosteroids and iTNF, and this should be considered whenever the test is repeated.

The Chart 1 shows the comparison between TST and IGRA tests.

\section{PREVALENCE OF LTBI IN RHEUMATIC DISEASES}

The prevalence of LTBI in patients with rheumatic disease was evaluated in some studies, ${ }^{(1,36-40)}$ usually by TST, variable results may be explained by differences in the selection of patients (which were included rheumatic diseases) or in the use of concomitant medications, especially corticosteroids.

The overall prevalence of LTBI was $13 \%$, of which $4 \%$ in Rheumatoid Arthritis (RA), $26 \%$ in Ankylosing Spondylitis (AS) and 23\% in Psoriatic Arthritis (PA), in a study performed in Fortaleza ${ }^{(37)}$ with 157 patients who were candidates for infliximab. The limited value of TST in this population was questioned, but the use of corticosteroids was not described, which may have interfered with TST results. Another study, conducted in Recife, evaluated 48 patients with RA who used prednisone, with a average dose of $12.7 \pm 6.7 \mathrm{mg}$ / day, with a low prevalence of LTBI (14.6\%). which can be explained at least partially by false-negative TST results, which may occur with doses $>15 \mathrm{mg}$ prednisone. ${ }^{(8)}$

Two other studies (1.38), also conducted in Brazil, showed higher prevalences. One of them, performed in São Paulo, ${ }^{(38)}$ evaluated 202 patients with RA, of which $32.7 \%$ had a diagnosis of LTBI. In addition, more than $80 \%$ of the patients selected used prednisone, but with a low dose $(9.9 \pm 5.3 \mathrm{mg} /$ day). Another study, conducted in Porto Alegre, ${ }^{(1)}$ included 176 patients with rheumatologic diseases (89 RA, 49 AS and 31 AP) and demonstrated a prevalence of LTBI of $29.5 \%$, despite the use of prednisone by $46.6 \%$ of 
Chart 1. Comparison between TST and IGRA tests.

\begin{tabular}{|c|c|}
\hline TST & IGRA \\
\hline False-positive by BCG and non-tuberculous mycobacteria. & $\begin{array}{l}\text { Results not affected by BCG vaccination and } \\
\text { non-tuberculous mycobacteria. }\end{array}$ \\
\hline False-negative immunosuppressants. & $\begin{array}{l}\text { Limited data on immunosuppressed (although it appears } \\
\text { to be less influenced by immunosuppression than TST) } \\
\text { and in patients recently exposed to Mycobacterium } \\
\text { tuberculosis. }\end{array}$ \\
\hline $\begin{array}{l}\text { - Sensitivity of } 77 \% \text { and specificity of } 97 \% \text { (not vaccinated } \\
\text { with BCG). } \\
\text { - Low and heterogeneous specificity - } 35 \% \text { to } 78.6 \% \\
\text { (vaccinated with BCG). }\end{array}$ & $\begin{array}{l}\text { - Sensitivity of } 78 \% \text { and specificity of } 99 \% \text { (not vaccinated } \\
\text { with BCG).* } \\
\text { - Specificity of } 98 \% \text { (vaccinated with BCG). }{ }^{*}\end{array}$ \\
\hline Possibility of variability among observers. & No possibility of variability between observers. \\
\hline Need for two visits (for reading the test). & Just a visit for blood collection. \\
\hline More time consuming results. & Faster results. \\
\hline Training needed to read the test result. & Need for qualified personnel and specialized equipment. \\
\hline Low Cost & High Cost \\
\hline
\end{tabular}

TST: tuberculin skin test; IGRA: interferon-gamma release assay; BCG: Calmette-Guérin bacillus. ${ }^{(8,34,35)} *$ Results for Quantiferon.

patients, with an average dose of $12.2 \pm 8.4 \mathrm{mg} /$ day. A similar prevalence was found in Peru (29.4\%), with all patients receiving prednisone at doses of $\leq 7.5 \mathrm{mg} /$ day. ${ }^{(36)}$ In India, a region with a high prevalence of TB, Agarwal et al. ${ }^{(39)}$ showed a $20.4 \%$ prevalence of LTBI, which was not affected by the use of methotrexate, but was lower in patients with recent corticosteroid use $(3 \%)$ compared to patients who did not used in the last three months $(25 \%)(p=0.0002)$.

\section{SCREENING RECOMMENDATIONS OF ILTB IN PATIENTS WITH RHEUMATOLOGIC DISEASES}

The WHO recommends that all patients that will begin treatment with iTNF are systematically tested and, if indicated, treated for LTBI. For the diagnosis of LTBI, both TST and IGRA tests can be used. In those patients without signs and symptoms of TB, active and positive for TST or IGRA, a chest radiograph should be requested to rule out the TB active. If the radiograph is negative, treatment for LTBI is indicated. ${ }^{(7)}$

But the Centers for Disease Control and Prevention (CDC) recommends giving high priority to the treatment of LTBI in individuals using iTNF drugs (or who will use them) and having a positive IGRA test or TST $\geq 5 \mathrm{~mm}$. For the diagnosis of $\mathrm{LTBi}$, it is advisable to perform the IGRA tests in the case of people vaccinated with BCG, as well as the request for a chest radiograph whenever an IGRA or TST is positive. Individuals with fibrotic or nodular lesions consistent with old TB are candidates with high priority to the treatment of LTBI, after excluding active TB. In addition, sputum bacilloscopy is indicated in patients with IGRA or positive TST and abnormal radiography or who present with respiratory symptoms (even with normal radiography). ${ }^{(41)}$

The recommendation of the Brazilian Ministry of Health (MS) is that all people who will start using iTNF drugs will be investigated for LTBI. If one of the IGRA tests is positive or there is a TST $\geq 5 \mathrm{~mm}$, the treatment of LTBI is indicated, as long as it excludes active TB. ${ }^{(8)}$
Finally, the American College of Rheumatology (ACR) recommends that screening be done to identify LTBI in all patients considered for treatment with biological agents, regardless of the presence of risk factors for LTBI. Both TST and IGRA tests can be used, however it is advisable to choose the latter in cases of BCG vaccinated patients. If TST is positive or the same for IGRA tests, it should be performed chest radiographs of patients. If the radiography is suggestive of active TB, sputum bacilloscopy should be performed to rule out TB. Since patients with RA may have false-negative results of the TST or IGRA tests due to immunosuppression, negative results should not be interpreted as excluding the possibility of LTBI. Thus, in patients with RA, risk factors for LTBI and negative initial tracing, the repetition of TST or IGRA tests is recommended between one and three weeks after the initial test. The annual screening is recommended in patients who live or work in places where there is a likelihood of exposure to $T B$, the duration of treatment with biological agents. ${ }^{(42,43)}$ It has already been shown that approximately $1 / 3$ of patients with negative baseline screening develop conversion into at least one screening test during treatment with iTNF. ${ }^{(44)}$

Patients who attested positive in TST or one of the IGRA may remain positive even after adequate treatment of LTBI or TB. In such cases, they require periodic monitoring of signs and symptoms of TB recurrence, since repeat testing is not useful in the diagnosis. In the ACR recommendations updated in 2015 , the only modification is that patients receiving Tofacitinib should follow the same guidelines as patients using biologicals. ${ }^{(42,43)}$

\section{TREATMENT OF LTBI}

The ACR recommends that treatment with biological is started or restarted after a month of treatment of LTBI or in the case of active TB after the completed 
TB treatment. In those patients using biologicals, it is suggested that these be suspended. ${ }^{(42,43)}$

The treatment regimens recommended for LTBI in patients with rheumatologic diseases follow the same norms as for the general population, always considering the presence of other comorbidities that may influence the therapeutic decision, in addition to monthly monitoring. $(7,8)$

The Isoniazid Monotherapy (INH) remains the most widely used treatment. It has already been evaluated in more than 20 randomized, placebo-controlled clinical trials, showing an average reduction in TB cases of $60 \%$, reaching up to $90 \%$ efficacy if adherence to treatment is good. Several treatment durations have been studied, but the most commonly recommended are six and nine months. ${ }^{(45,46)}$ On the other hand, the duration of protection ranges according to the duration of follow-up studies, being five years in most studies with isoniazid, although the protective effect is greater in the first year after treatment. (45)

Another form of treatment is rifampicin (RMP) by monotherapy, used for four months. It was evaluated in several small non-randomized clinical trials, demonstrating efficacy equal to or greater than six months of INH. ${ }^{(45,46)}$ A randomized clinical trial ${ }^{(47)}$ in Chinese patients with silicosis showed that RMP monotherapy, used for three months, was more effective than placebo, INH for six months and combination of INH with RMP for three months. Recently, another open, randomized and multicenter clinical trial, the RMP for four months was not lesser than INH for nine months ${ }^{(48)}$ and also showed higher rates of completion of treatment. The RMP monotherapy is also considered an alternative for locations with high proportion of INH mono-resistance, in case of intolerance to INH and for those patients unlikely to complete six months of INH. ${ }^{(45,46)}$

The combination of RMP and INH for three / four months is also a possibility for LTBI treatment. A metaanalysis made in 2005, ${ }^{(49)}$ including studies in Hong Kong, Spain, and Uganda, showed that the RMP plus INH regimen for three months had equal efficacy and adverse effects profile similar to INH regimens lasting 6 to 12 months. However, it has been shown that the incidence of hepatitis with this regimen is only lower than the INH regimens used for 12 months; when compared to INH for six to nine months; the incidence of hepatitis is significantly higher. ${ }^{(50)}$

The rifapentine (RPT) plus INH regimen, which has been used with a weekly dose for three months for a total of 12 doses and recommended since 2011 by the $\mathrm{CDC}$, has been evaluated in at least three randomized controlled trials ${ }^{(51-53)}$ and in a meta-analysis, ${ }^{(54)}$ showing to be as effective as INH monotherapy, with higher rates of treatment completion and less hepatotoxicity. However, recent research ${ }^{(55,56)}$ with adults aged 50 to 70 years, who were randomized to receive one of two short regimens containing rifapentine (three months of RPT plus INH or two months of RPT 600 mg twice a week, plus INH $600 \mathrm{mg}$ ) had to be discontinued prematurely due to the high rate of adverse events. Although studies have methodological limitations, these findings raise concerns about the use of RPT more INH in older adults and require a more careful evaluation. The CDC still suggests several layouts: INH for six or nine months, RIF for four months and RPT plus INH for three months. ${ }^{(41)}$

The WHO recommends the first choice of treatment for INH for six months. For locations with high incidence of TB, it suggests the most INH plus RPT layout for three months and, for locations with low incidence of TB, INH for nine months, RPT more INH for three months, RIF more INH for three / four months and RIF three / four-months. ${ }^{(7)}$

On the other hand, the recommendation of the Brazilian Ministry of Health (MH) for the treatment of LTBI is INH at a dose of 5 to $10 \mathrm{mg} / \mathrm{kg} /$ day up to a maximum dose of $300 \mathrm{mg} /$ day in adults, lasting six to nine months; however, it is considered that the most important is the number of doses, and not only the time of treatment. It is also indicated the use of 270 doses, taken from 9 to 12 months, and 180 doses, taken between six and nine months, but only considered in individual cases after assessment of adherence. However, there is evidence that the use of 270 doses protects more than 180 doses.

The Ministry of Health (MH) also suggests RMP for four months as an option for individuals over 50 years of age, liver disease people, with contacts of INH mono-resilients and intolerance to $\mathrm{INH}$, at the dose of $10 \mathrm{mg} / \mathrm{kg} /$ day of weight up to the maximum dose of $600 \mathrm{mg} /$ day in adults. In this case, the use must be at least 120 doses, taken for four months, and may extend up to six months. ${ }^{(8)}$ It is also considered that the most important is the number of doses, and not only the time of treatment.

The Chart 2 summarizes the main treatment layout.

\section{CONCLUSIONS}

In $5-10 \%$ of individuals with impaired immune response to $\mathrm{Mtb}$, the LTBI can progress to active TB. Therefore, screening for LTBI is strongly recommended in patients with rheumatic diseases, especially before starting treatment with iTNF. The screening always involves the exclusion of active TB, and the recommendation of the test of choice (TST or IGRA) may vary according to BCG vaccination and the costs and availability of the tests. The first choice of treatment remains the INH for six to nine months, with the RMP for four months as a treatment option. Individuals living in areas with high incidence of TB should be tested annually for LTBI, the duration of the treatment iTNF.

Despite the diagnosis and treatment advances in this area, there are still some gaps in the knowledge of LTBI in patients with rheumatic diseases. There is a need for a diagnostic test with better performance and shorter treatment regimens and with fewer adverse effects. Besides that, it is important to assess the 
Chart 2. LTBI treatment layouts.

\begin{tabular}{|c|c|c|c|}
\hline Layouts & Dose & Duration & Observations \\
\hline Isoniazid & $\begin{array}{l}5 \text { to } 10 \mathrm{mg} / \mathrm{kg} / \text { day of weight up to the } \\
\text { maximum dose of } 300 \mathrm{mg} / \text { day in adults. } \\
\text { It is recommended to use } 270 \text { doses. }\end{array}$ & 6 a 9 months. & $\begin{array}{l}\text { First choice of treatment, according } \\
\text { to WHO and MH Brazil. }\end{array}$ \\
\hline Rifampicin & $\begin{array}{l}10 \mathrm{mg} / \mathrm{kg} / \text { day of weight up to the } \\
\text { maximum dose of } 600 \mathrm{mg} \text { per day in adults. } \\
\text { It is recommended to use at least } 120 \text { doses. }\end{array}$ & 4 months. & $\begin{array}{l}\text { Option for individuals over } 50 \text { years } \\
\text { old, liver disease, with mono- } \\
\text { resilient contacts to INH and INH } \\
\text { intolerance. }\end{array}$ \\
\hline $\begin{array}{l}\text { Isoniazid plus } \\
\text { Rifapentine }\end{array}$ & $\begin{array}{l}\text { One weekly dose: } \\
\text { Isoniazid } 15 \mathrm{mg} / \mathrm{kg} \text { (maximum } 900 \mathrm{mg} \text { ). } \\
\text { Rifapentine: } 900 \mathrm{mg} \text { (> } 50 \mathrm{~kg} \text { ). }\end{array}$ & $\begin{array}{l}3 \text { months } \\
\text { (Total of } \\
12 \text { doses). }\end{array}$ & Not available in Brazil. \\
\hline $\begin{array}{l}\text { Isoniazid plus } \\
\text { Rifampicin }\end{array}$ & $\begin{array}{l}\text { Isoniazid: } 5 \mathrm{mg} / \mathrm{kg} / \text { day (maximum of } 300 \\
\text { mg / day). } \\
\text { Rifampicin: } 10 \mathrm{mg} / \mathrm{kg} / \text { day (maximum of } \\
600 \mathrm{mg} \text { ). }\end{array}$ & 3-4 months. & $\begin{array}{l}\text { Hepatitis incidence greater than } \\
\text { isoniazid for } 6-9 \text { months. }\end{array}$ \\
\hline
\end{tabular}

risk of resistance to the treatment of LTBI, especially in cases with low adherence. Finally, there are few studies that analyze the best follow-up strategy for these patients.

\section{REFERENCES}

1. Garziera G, Morsch ALB, Otesbelgue F, Staub FL, Palominos PE Brenol CV, et al. Latent tuberculosis infection and tuberculosis in patients with rheumatic diseases treated with anti-tumor necrosis factor agents. Clin Rheumatol. 2017;36(8):1891-6. http://dx.doi. org/10.1007/s10067-017-3714-6. PMid:28589321.

2. Mack U, Migliori GB, Sester M, Rieder HL, Ehlers S, Goletti D, et al. LTBI: latent tuberculosis infection or lasting immune responses to M. tuberculosis? A TBNET consensus statement. Eur Respir J 2009;33(5):956-73. http://dx.doi.org/10.1183/09031936.00120908. PMid:19407047

3. WHO: World Health Organization. Global tuberculosis report 2018 [Internet]. Switzerland: WHO; 2018 [cited 2019 Jan 20]. Available from: www. who.int

4. Ishiguro T, Takayanagi N, Kagiyama N, Yanagisawa T, Sugita $Y$ Characteristics of tuberculosis in patients with rheumatoid arthritis: a retrospective single-center study. Intern Med. 2014;53(12):1291-8. http://dx.doi.org/10.2169/internalmedicine.53.1936. PMid:24930647.

5. Baronnet L, Barnetche T, Kahn V, Lacoin C, Richez CST, Schaeverbeke $\mathrm{T}$. Incidence of tuberculosis in patients with rheumatoid arthritis. A systematic literature review. Joint Bone Spine. 2011;78(3):279-84. http://dx.doi.org/10.1016/j.jbspin.2010.12.004. PMid:21273108.

6. Alawneh KM, Ayesh MH, Khassawneh BY, Saadeh SS, Smadi M Bashaireh K. Anti-TNF therapy in Jordan: a focus on severe infections and tuberculosis. Biologics. 2014;8:193-8. http://dx.doi.org/10.2147/ BTT.S59574. PMid:24790412.

7. 7. WHO: World Health Organization. Latent tuberculosis infection Updated and consolidated guidelines for programmatic management. Switzerland: WHO; 2018

8. Brasil. Manual de recomendações para o controle da tuberculose no Brasil [Internet]. Brasília: Ministério da Saúde; 2018 [cited 2019 Jan 20]. Available from: www.saude.gov.br

9. Arkema EV, Jonsson J, Baecklund E, Bruchfeld J, Feltelius N, Askling $J$ et al. Are patients with rheumatoid arthritis still at an increased risk of tuberculosis and what is the role of biological treatments? Ann Rheum Dis. 2015;74(6):1212-7. http://dx.doi.org/10.1136/ annrheumdis-2013-204960. PMid:24608401

10. Askling J, Fored CM, Brandt L, Baecklund E, Bertilsson L, Cöster $L$, et al. Risk and case characteristics of tuberculosis in rheumatoid arthritis associated with tumor necrosis factor antagonists in Sweden. Arthritis Rheum. 2005;52(7):1986-92. http://dx.doi. org/10.1002/art.21137. PMid:15986370.

11. Carmona L, Hernández-García C, Vadillo C , Pato E, Balsa A, GonzálezAlvaro l et al. Increased risk of tuberculosis in patients with rheumatoid arthritis. J Rheumatol. 2003;30(7):1436-9. PMid:12858438.

12. 12. Scrivo $R$, Armignacco $O$. Tuberculosis risk and anti-tumour necrosis factor agents in rheumatoid arthritis: a critical appraisal of national registry data. Int J Rheum Dis. 2014;17(7):716-24. http:// dx.doi.org/10.1111/1756-185X.12375. PMid:24725559.

13. Seong S-S, Choi C-B, Woo J-H, Bae KW, Joung C-L, Uhm W-S, et al
Incidence of tuberculosis in Korean patients with rheumatoid arthritis (RA): effects of RA itself and of tumor necrosis factor blockers. $J$ Rheumatol. 2007;34(4):706-11. PMid:17309133.

14. Yonekura CL, Oliveira RDR, Titton DC, Ranza R, Ranzolin A, Hayata $\mathrm{AL}$, et al. Incidence of tuberculosis among patients with rheumatoid arthritis using TNF blockers in Brazil: data from the Brazilian Registry of Biological Therapies in Rheumatic Diseases. Rev Bras Reumato Engl Ed. 2017:57(Suppl 2):477-83. http://dx.doi.org/10.1016/j. rbr.2017.05.003. PMid:28739353

15. Mohan VP, Scanga CA, Yu K, Scott HM, Tanaka KE, Tsang E, et al. Effects of tumor necrosis factor alpha on host immune response in chronic persistent tuberculosis: possible role for limiting pathology. Infect Immun. 2001;69(3):1847-55. http://dx.doi.org/10.1128/ IAl.69.3.1847-1855.2001. PMid:11179363

16. Solovic I, Sester M, Gomez-Reino JJ, Rieder HL, Ehlers S, Milburn $\mathrm{HJ}$, et al. The risk of tuberculosis related to tumour necrosis factor antagonist therapies: a TBNET consensus statement. Eur Respir J. 2010;36(5):1185-206. http://dx.doi.org/10.1183/09031936.00028510. PMid:20530046

17. Cantini F, Niccoli L, Goletti D. Tuberculosis risk in patients treated with non-anti-tumor necrosis factor- $\mathbf{\square}$ (TNF- $\mathbf{\square}$ ) targeted biologics and recently licensed TNF- $\mathbf{a}$ inhibitors: data from clinical trials and nationa registries. J Rheumatol Suppl. 2014;91(0):56-64. http://dx.doi. org/10.3899/jrheum.140103. PMid:24789001.

18. Conde MB, de Melo FAF, Marques AMC, Cardoso NC, Pinheiro VGF, Dalcin PTR, et al. III Brazilian thoracic association guidelines on tuberculosis. J Bras Pneumol. 2009;35(10):1018-48. http://dx.doi. org/10.1590/S1806-37132009001000011. PMid:19918635.

19. Chan PC, Chang LY, Wu YC, Lu CY, Kuo HS, Lee CY, et al. Agespecific cut-offs for the tuberculin skin test to detect latent tuberculosis in BCG-vaccinated children. Int J Tuberc Lung Dis. 2008;12(12):1401-6. PMid:19017449.

20. Araujo Z, Waard JH, de Larrea CF, Borges R, Convit J. The effect of Bacille Calmette-Guérin vaccine on tuberculin reactivity in indigenous children from communities with high prevalence of tuberculosis. Vaccine. 2008;26(44):5575-81. http://dx.doi.org/10.1016/j. vaccine.2008.08.006. PMid:18723065

21. Panayi GS, Corrigall VM, Pitzalis C. Pathogenesis of rheumatoid arthritis: the role of $t$ cells and other beasts. Rheum Dis Clin North Am. 2001;27(2):317-34. http://dx.doi.org/10.1016/S0889 857X(05)70204-0. PMid:11396095.

22. Martins MVBS, Lima MCBS, Duppre NC, Matos HJ, Spence JS, Brennan PJ, et al. The level of PPD-specific IFN-a-producing CD4+ $T$ cells in the blood predicts the in vivo response to PPD. Tuberculosis (Edinb). 2007;87(3):202-11. http://dx.doi.org/10.1016/j. tube.2006.07.006. PMid:17049309.

23. Ehrenstein MR, Evans JG, Singh A, Moore S, Warnes G, Isenberg $D A$, et al. Compromised Function of Regulatory $T$ Cells in Rheumatoid Arthritis and Reversal by Anti-TNFo Therapy. J Exp 
Med. 2004;200(3):277-85. http://dx.doi.org/10.1084/jem.20040165 PMid:15280421.

24. Kim J-H, Cho S-K, Han M, Choi C-B, Kim T-H, Jun J-B, et al. Factors influencing discrepancies between the QuantiFERON-TB gold in tube test and the tuberculin skin test in korean patients with rheumatic diseases. Semin Arthritis Rheum. 2013;42(4):424-32. http://dx.doi. org/10.1016/j.semarthrit.2012.07.001. PMid:22858451.

25. Bartalesi F, Goletti D, Spinicci M, Cavallo A, Attala L, Mencarini J, et al. Serial QuantiFERON TB-Gold in-tube testing during LTBI therapy in candidates for TNFi treatment. J Infect. 2013;66(4):346-56. http:// dx.doi.org/10.1016/j.jinf.2012.10.017. PMid:23103667.

26. Emery P, Panayi G, Symmons D, Brown G. Mechanisms of depressed delayed-type hypersensitivity in rheumatoid arthritis: the role of protein energy malnutrition. Ann Rheum Dis. 1984;43(3):4304. http://dx.doi.org/10.1136/ard.43.3.430.

27. Köker IH, Pamuk ON, Karlikaya C, Tuncbilek N, Cakir N. A low prevalance of purified protein derivative test positivity in Turkish patients with rheumatoid arthritis. Association with clinical features and HRCT findings. Clin Exp Rheumatol. 2007;25(1):54-9. PMid:17417991.

28. Marques CDL, Duarte ÂLBP, Lorena VMB, Souza JR, Souza W, Gomes YM, et al. Resposta atenuada ao PPD no diagnóstico de infecção tuberculosa latente em pacientes com artrite reumatoide. Rev Bras Reumatol. 2009;49(2):121-25. http://dx.doi.org/10.1590/ S0482-50042009000200004.

29. Lalvani A. Diagnosing tuberculosis infection in the 21st century: new tools to tackle an old enemy. Chest. 2007;131(6):1898-906. http:// dx.doi.org/10.1378/chest.06-2471. PMid:17565023.

30. Teutschbein J, Schumann G, Möllmann U, Grabley S, Cole ST, Munder T. A protein linkage map of the ESAT-6 secretion system 1 (ESX-1) of Mycobacterium tuberculosis. Microbiol Res. 2009;164(3):253-9. http://dx.doi.org/10.1016/j.micres.2006.11.016. PMid: 17433643

31. Hoffmann M, Tsinalis D, Vernazza P, Fierz W, Binet I. Assessment of an Interferon- $\mathbf{\square}$ release assay for the diagnosis of latent tuberculosis infection in haemodialysis patients. Swiss Med Wkly. 2010;140(1920):286-92. PMid:20131112.

32. Pai M, Denkinger CM, Kik SV, Rangaka MX, Zwerling A, Oxlade O, et al. Gamma interferon release assays for detection of Mycobacterium tuberculosis infection. Clin Microbiol Rev. 2014;27(1):3-20. http:// dx.doi.org/10.1128/CMR.00034-13. PMid:24396134.

33. Ruan $\mathrm{Q}$, Zhang S, Ai J, Shao L, Zhang W. Screening of latent tuberculosis infection by interferon- $\mathbf{\square}$ release assays in rheumatic patients: a systemic review and meta-analysis. Clin Rheumatol. 2016;35(2):417-25. http://dx.doi.org/10.1007/s10067-014-2817-6. PMid:25376466.

34. Handa R, Upadhyaya S, Kapoor S, Jois R, Pandey BD, Bhatnagar $A K$, et al. Tuberculosis and biologics in rheumatology: A special situation. Int J Rheum Dis. 2017;20(10):1313-25. http://dx.doi. org/10.1111/1756-185X.13129. PMid:28730751.

35. Pai M, Zwerling A, Menzies D. Systematic review: T-Cell - based assays for the diagnosis of latent tuberculosis infection. Ann Intern Med. 2008;149(3):177-12. PMid:18593687.

36. León DP, Acevedo-Vásquez E, Sánchez-Torres A, Cucho M, Alfaro $J$, Perich $R$, et al. Attenuated response to purified protein derivative in patients with rheumatoid arthritis: study in a population with a high prevalence of tuberculosis. Ann Rheum Dis. 2005;64(9):1360-1. http://dx.doi.org/10.1136/ard.2004.029041. PMid:16100342.

37. Callado MRM, Lima JRC, Nobre CA, Vieira WP. Baixa prevalência de PPD reativo prévia ao uso de infliximabe: estudo comparativo em população amostral do Hospital Geral de Fortaleza. Rev Bras Reumatol. 2011;51(1):46-52. http://dx.doi.org/10.1590/S048250042011000100004. PMid:21412605.

38. Bonfiglioli KR, Ribeiro ACM, Moraes JCB, Saad CGS, Souza FHC, Calich AL, et al. LTBI screening in rheumatoid arthritis patients prior to anti-TNF treatment in an endemic area. Int J Tuberc Lung Dis. 2014;18(8):905-11. PMid:25199003.

39. Agarwal S, Das SK, Agarwal GG, Srivastava R. Steroids decrease prevalence of positive tuberculin skin test in rheumatoid arthritis: Implications on anti-TNF therapies. Interdiscip Perspect Infect Dis. 2014;2014:430134. http://dx.doi.org/10.1155/2014/430134. PMid:24707285.
40. Saidenberg-Kermanac'h $N$, Semerano L, Naccache JM, Brauner M, Falgarone G, Dumont-Fischer D, et al. Screening for latent tuberculosis in anti-TNF-0 candidate patients in a high tuberculosis incidence setting. Int J Tuberc Lung Dis. 2012;16(10):1307-14. http:// dx.doi.org/10.5588/ijtld.12.0111. PMid:22863801.

41. CDC: Centers for Disease Control and Prevention. LTBI: a guide for primary health care providers - Diagnosis of latent TB infection [Internet]. Atlanta: CDC; 2019 [cited 2019 Jan 20]. Available from: https://www.cdc.gov/tb/publications/tbi/diagnosis. htm\#specialConsiderationstb

42. Singh JA, Furst DE, Bharat $A$, Curtis JR, Kavanaugh $A F$, Kremer JM, et al. 2012 update of the 2008 American college of rheumatology recommendations for the use of disease-modifying antirheumatic drugs and biologic agents in the treatment of rheumatoid arthritis. Arthritis Care Res. 2012;64(5):625-9. http://dx.doi.org/10.1002/ acr.21641. PMid:22473917

43. Singh JA, Saag KG, Bridges SL Jr, AkI EA, Bannuru RR, Sullivan MC, et al. 2015 American college of rheumatology guideline for the treatment of rheumatoid arthritis. Arthritis Care Res. 2016;68(1):1-25. http://dx.doi.org/10.1002/acr.22783. PMid:26545825.

44. Hatzara C, Hadziyannis E, Kandili A, Koutsianas C, Makris A, Georgiopoulos G, et al. Frequent conversion of tuberculosis screening tests during anti-tumour necrosis factor therapy in patients with rheumatic diseases. Ann Rheum Dis. 2015;74(10):1848-53. http:// dx.doi.org/10.1136/annrheumdis-2014-205376. PMid:24854354.

45. Haley CA. Treatment of latent tuberculosis infection. Microbiol Spectr. 2017;5(2):TNMI7-0039-2016. http://dx.doi.org/10.1128/ microbiolspec.TNMI7-0039-2016. PMid:28409555.

46. Tang P, Johnston J. Treatment of latent tuberculosis infection. Curr Treat Options Infect Dis. 2017;9(4):371-9. http://dx.doi.org/10.1007/ s40506-017-0135-7. PMid:29238270.

47. Hong Kong Chest Service, Tuberculosis Research Centre, MMRC: Madras/British Medical Research Council. A double-blind placebocontrolled clinical trial of three antituberculosis chemoprophylaxis regimens in patients with silicosis in Hong Kong. Am Rev Respir Dis. 1992;145(1):36-41. http://dx.doi.org/10.1164/ajrccm/145.1.36 PMid:1731596.

48. Menzies D, Adjobimey M, Ruslami R, Trajman A, Sow O, Kim $H$, et al. Four months of rifampin or nine months of isoniazid for latent tuberculosis in adults. N Engl J Med. 2018;379(5):440-53. http:// dx.doi.org/10.1056/NEJMoa1714283. PMid:30067931.

49. Ena J, Valls V. Short-course therapy with rifampin plus isoniazid, compared with standard therapy with isoniazid, for latent tuberculosis infection: a meta-analysis. Clin Infect Dis. 2005;40(5):670-6. http:// dx.doi.org/10.1086/427802. PMid:15714411.

50. Steele MA, Burk RF, DesPrez RM. Toxic hepatitis with isoniazid and rifampin. Chest. 1991;99(2):465-71. http://dx.doi.org/10.1378/ chest.99.2.465. PMid:1824929.

51. Martinson NA, Barnes GL, Moulton LH, Msandiwa R, Hausler $H$, Ram $M$, et al. New regimens to prevent tuberculosis in adults with HIV infection. N Engl J Med. 2011;365(1):11-20. http://dx.doi. org/10.1056/NEJMoa1005136. PMid:21732833.

52. Schechter M, Zajdenverg R, Falco G, Barnes GL, Faulhaber JC Coberly JS, et al. Weekly rifapentine isoniazid or daily rifampin pyrazinamide for latent tuberculosis in household contacts. Am J Respir Crit Care Med. 2006;173(8):922-6. http://dx.doi.org/10.1164/ rccm.200512-19530C. PMid:16474028.

53. Sterling TR, Villarino ME, Borisov AS, Shang N, Gordin F, BlivenSizemore $E$, et al. Three months of rifapentine and isoniazid for latent tuberculosis infection. N Engl J Med. 2011;365(23):2155-66. http:// dx.doi.org/10.1056/NEJMoa1104875. PMid:22150035.

54. Njie GJ, Morris SB, Woodruff RY, Moro RN, Vernon AA, Borisov AS. Isoniazid-rifapentine for latent tuberculosis infection: a systematic review and meta-analysis. Am J Prev Med. 2018;55(2):244-52. http:// dx.doi.org/10.1016/j.amepre.2018.04.030. PMid:29910114.

55. Gao L, Zhang H, Xin H, Liu J, Pan S, Li X, et al. Short-course regimens of rifapentine plus isoniazid to treat latent tuberculosis infection in older Chinese patients: a randomised controlled study. Eur Respir J. 2018;52(6):1801470. http://dx.doi.org/10.1183/13993003.014702018. PMid:30361241.

56. Menzies D, Trajman A. New short regimens for latent tuberculosis treatment: safety first! Eur Respir J. 2018;52(6):1802180. http:// dx.doi.org/10.1183/13993003.02180-2018. PMid:30573695. 